\title{
SAPPHO, HEGEL AND MICHAEL FIELD: PARADOX AND DESIRE IN LYRIC III
}

\author{
Mayron Estefan Cantillo-Lucuara \\ Universitat de València
}

\begin{abstract}
This article offers a close reading of Katharine Bradley and Edith Cooper's lyric III in Long Ago, a Sapphic volume of verse published in 1889 under the collaborative nom de plume of Michael Field. This collection articulates a dramatic inquiry into the tragedy of unrequited love in a long cycle of lyrics whose third piece most effectively encapsulates the kernel of what the Fields reconstruct as Sappho's ambivalent eroticism. The outcome of this reconstruction, as analysed in light of lyric III, is a consistent Hegelian view of desire that subsumes a complex system of tropes, myths, paradoxes and imaginative strategies under an overarching ideology of desire as a radical experience of appropriation, violence and self-destruction.
\end{abstract}

KEYWORDS: Michael Field, Long Ago, Sappho, Hegel, lyric III, desire

\section{Safo, Hegel y Michael Field: Paradoja y deseo en la lírica III}

\begin{abstract}
RESUMEN: El presente artículo propone una lectura pormenorizada de la pieza lírica III de Long Ago, un poemario publicado en 1889 por Katharine Bradley y Edith Cooper bajo el pseudónimo compartido de Michael Field. Esta colección articula un discurso dramático en torno a la tragedia del amor no correspondido en un ciclo extenso de poemas líricos cuya tercera pieza reúne de modo muy efectivo el sentido pleno de lo que las Fields reconstruyen como el erotismo ambivalente de Safo. El resultado de esta reconstrucción es, a la luz del poema III, una visión hegeliana del deseo que inscribe un sistema complejo de tropos, mitos, paradojas y estrategias imaginativas dentro de una ideología general del deseo como experiencia radical de apropiación, violencia y autodestrucción.
\end{abstract}

PALABRAS CLAVE: Michael Field, Long Ago, Safo, Hegel, poema III, deseo

\section{INTRODUCTION}

In 1889, Victorian poets Katharine Bradley and Edith Cooper, jointly known as Michael Field, garnered limited yet noble recognition as original lyrical voices after the release of Long Ago, a volume of verse based on Sappho's fragments. Robert Browning, John Addington Symonds, Walter Pater and George Meredith commended the Fields for the highly sophisticated and suggestive quality of their poems, their Hellenic elegance, their "Attic 
wisdom" (Pater in Vadillo, 2014, 39), their command of "the uses of Greek learning" (Browning in Field, 1933, 31), and their "faultless flow" and "classic concision" (Meredith in Leighton, 1992, 212). After nearly a century of practical neglect, Long Ago reemerged as an appealing collection in the 1990s thanks to the pioneering work of Angela Leighton (1992), Chris White (1990, 1996), Virginia Blain (1996) and Yopie Prins (1999). In the wake of this rediscovery, there has been a significant turn in the reception of the Fields' Sapphic volume, moving from a late Victorian celebration of its pagan Hellenism to a postmodern defence of its lesbian queerness. Stetz and Wilson (2007), Ed Madden (2008), Marion Thain (2009), Stefano Evangelista (2009) Tracy Olverson (2010), Mayron Cantillo-Lucuara (2018a) and, even more recently, Kate Thomas (2019) have systematically partaken in a concerted effort to consecrate Long Ago as a sophisticated fin-de-siècle model of queer desire. ${ }^{1}$

There is no denying that the Fields devote several poems to the representation of lesbian eroticism in Long Ago, but this should not obliterate the fact that the bulk of the volume focuses on Sappho's heteroerotic desire for her beloved ferryman Phaon in a spirit of amplifying and dramatising the archetypal representation of Sappho as a suicidal lover. This archetype - particularly in its Ovidian version in the Epistulae Heroidum - is "the one bequeathed to posterity, for many centuries the definitive, forlorn, love-struck, and suicidal poet who has given up the love of women for an unrequited passion for a young man" (duBois, 2015, 108). In Long Ago, it is specifically the third lyric piece that most clearly introduces and renews the drama of Sappho's unreciprocated passion for Phaon in an aesthetic and paradoxical idiom of floral metaphors and extreme romantic ideals.

This article proposes to thoroughly examine such a poetic idiom in light of Hegel's conception of desire. Marion Thain $(2007,36)$ has rightly noted that the Fields were avid readers of "the German philosophers" - particularly Hegel and Nietzsche. Indeed, in a revealing letter to American art critic Bernard Berenson, Edith Cooper confesses: "Hegel's Aesthetic belongs to me, though Michael [Katharine] claimed it, as all mine is his" (in Thain and Vadillo, 2009, 323). I contend that this possessive advocacy of Hegelianism finds its fullest poetic expression in the ways the Fields approach female desire in lyric III. In the famous second section of his Phenomenology of Spirit, ${ }^{2}$ Hegel posits the notion of desire - die Begierde - as a complex drive that leads the subject to confront the other in a belligerent and destructive agon:

${ }^{1}$ I have departed from this common reading of Long Ago in other articles of mine, in which the volume is interpreted as a paradigmatic case of intertextual theory (Cantillo-Lucuara, 2018b) and as a mythopoetic text systematically constructed around tragic Graeco-Roman motifs (Cantillo-Lucuara, 2018c).

${ }^{2}$ I will be making a systematic use of Hegel's Phenomenology of Spirit as translated by A. V. Miller in 1979 for Oxford University Press. 
Certain of the nothingness of this other, it [the subject] explicitly affirms that this nothingness is for it the truth of the other; it destroys the independent object and thereby gives itself the certainty of itself as a true certainty, a certainty which has become explicit for selfconsciousness itself in an objective manner (109).

Robert Stern's commentary $(2002,73)$ on this complex yet critical passage sheds ample light on what desire means to Hegel: "with desire the subject attempts to preserve its individuality by negating the world around it. The difficulty with desire, however, is that it involves the destruction of the object". Informed by this agonistic piece of Hegelianism, I seek to reveal how Long Ago's lyric III excels in articulating an inquiry into the tragic nature of desire by means of a rich tropology of vegetative and apian metaphors, which participate in a subversive ideology that transforms female desire into a radical and paradoxical experience of ownership, voracity and (self)destruction. Poem III reads in full as follows:

$\mathrm{OH}$, not the honey, nor the bee!

Yet who can drain the flowers

As I? Less mad, Persephone

Spoiled the Sicilian bowers

Than I for scent and splendour rove

The rosy oleander grove,

Or lost in myrtle nook unveil

Thoughts that make Aphrodite pale.

Honey nor bee! the tingling quest

Must that too be denied?

Deep in thy bosom I would rest,

O golden blossom wide!

$\mathrm{O}$ poppy-wreath, $\mathrm{O}$ violet-crown,

I fling your fiery circlets down;

The joys o'er which bees murmur deep

Your Sappho's senses may not steep.

Honey! clear, soothing, nectarous, sweet,

Oh which my heart would feed,

Give me, O Love, the golden meat,

And stay my life's long greed-

The food in which the gods delight

That glistens tempting in my sight!

Phaon, thy lips withhold from me

The bliss of honey and of bee (ll. 1-24). 


\section{STRUCTURAL PARADOX AND SYMBOLIC VIOLENCE IN THE FIRST OCTAVE}

Poem III opens in an exclamatory tone that promises to raise the intensity of Sappho's desire for her absent and reticent Phaon, who was briefly introduced in the previous lyric. Indeed, this intensification becomes manifest on the level of form itself with the addition of another quatrain of two couplets to the former elegiac stanzas that make up the second poem, resulting now in a sequence of three octaves. The merging of two quatrains into a single unit, together with their interlaced rhyme scheme, not only endows Sappho's desire with a growing exuberance, but also formalises her urgent need for erotic union with her elusive beloved.

However, the erotic union Sappho aspires to attain is met with extreme antagonism. The first line of poem III factually disrupts the formal ideal of fusion. While the three octaves and their internal couplets seem to create the effect or illusion of junction, the crude lexical meaning of the opening line points to Sappho's tragedy of romantic disjunction. A clear paradox arises here: form and content oppose each other, the former intimating an ideal or a dream, and the latter cancelling out such an ideal and reminding Sappho of her barren reality and her inability to be a sweet beloved or an apian lover. As a result, what Terry Eagleton $(2007,65)$ posits as "the mimetic theory of form, for which the form somehow imitates the content it expresses", loses its validity in this case. Sappho is ambivalently poised between her formal dreams and her actual romantic sterility. Put in Hegelian jargon, Sappho inhabits an anxious state of "freedom enmeshed in servitude" $(1979,119)$ or of "incomplete self-certainty" $(1979,132)$. Formally or imaginatively, the Sapphic dream of erotic synthesis is realised, but factually her desire is negated altogether.

There is more to the opening line. In her denied wish to be either honey or bee, the lyric subject renders her sexuality ambiguous. Binary thinking is debunked in favour of a Hegelian logic of desire. Sappho tacitly portrays herself as the draining bee or the resultant honey with no either/or scheme at work. Her desire does not privilege one option over the other, but rather aspires to fulfil them both. Establishing a metaphoric disjunction between honey and bee, tantamount to the passivity/activity dichotomy, she suspends the opposition between both terms and vouches for a coveted intertwining of the two. The penetrative bee, which drains and pollinates flowers, and the honey, which is produced and depleted, lose their antithetical values and give rise to what Hegel $(1979,278)$ would define as a "union which converts two syllogisms into one and the same syllogism, and unites into one process the opposite movements". However, the crude fact remains that the Sapphic lover does not stand a chance to enjoy either of the roles - let alone their promising conflation. It is only her exclamatory desire that remains vibrant and persists inexorably in a mad quest to become the bee and the honey for her loved one.

So intense is Sappho's passion that she sees no possible rival capable of surpassing her penetrative power: "Yet who can drain the flowers / As I?" (ll. 2-3). In this rhetorical inquiry, another structural paradox occurs: the violence of the bare infinitive clashes with the delicate language of honey and flowers. It seems that Sappho best articulates her desire in antithetical 
terms, and this inherent antithesis serves to hint at the richness and complexity of Sappho's erotic identity. Her love is not a mere infatuation or whim. She covets her beloved with delicacy and tenderness, but also with violence and even madness: "Less mad, Persephone / Spoiled the Sicilian bowers" (1l. 3-4). The allusion to the Queen of the Underworld enhances and subverts the erotic nature of the poem. Persephone intervenes not as an unfortunate girl famously kidnapped by Hades, but as an active figure of natural aggression comparable to a bee spoiling or draining flowers. The Fields put the original myth upside down. Hades is an absence. His sexual violence is replaced with Persephone's freedom in the middle of the wilderness. It is her story that gains full centrality in poem III, where Sappho seems to be evoking the initial portrayal of the goddess in the Homeric Hymn to Demeter:

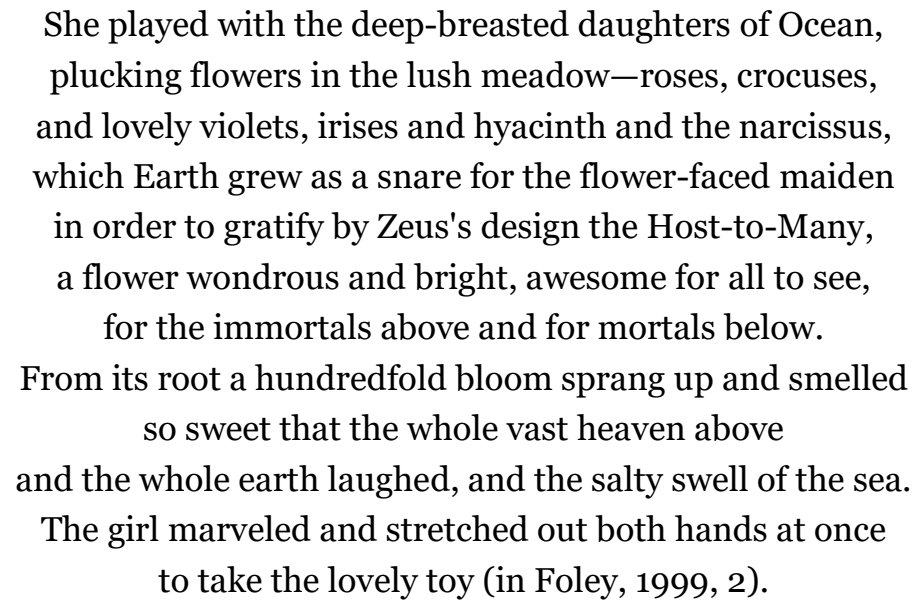

In a self-projective fashion, Sappho centres on the symbolism of Persephone's agency and freedom as a gatherer of flowers, and yet this self-projection is cast in such a way that Sappho depicts herself as more active and insane than her divine counterpart. With greater frenzy, Sappho spoils groves and nooks in search of her most coveted flower. She becomes an erotic nomad hunting for scented and splendid pleasure in a persistent bee-sounding rhythm

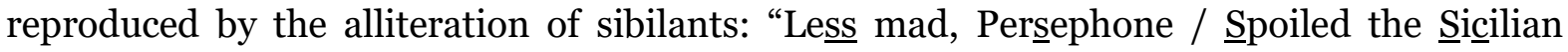
bowers / Than I for scent and splendour rove” (ll. 3-5). Additionally, the syntax of these alliterative lines reflects the despair and madness of the Sapphic erotic journey: the usual correlation between 'less' and 'than' is split up in a radical hyperbaton by an intrusive sentence in the middle while the prepositional complements precede their governing verbs in a convoluted construction dictated by a frantic and avid type of desire.

On her erotic journey, the Sapphic nomad's sense of power gains further enhancement with the suggestive allusion to the myrtle, an evergreen flower which belongs to the iconic domain of Aphrodite and thus typifies seduction, inebriation, female pleasure, and lust. ${ }^{3}$ As

3 Ferber notes some of these values and adds that the plant is oftentimes present in the creation of floral crowns and garlands. Naturally, this significant presence turns the Aphroditean bloom into yet another symbol of the erotic union or intertwining that Sappho pursues desperately in Long Ago: "The myrtle plant was sacred to Aphrodite and to her Roman counterpart Venus, as it was to the 
might be expected, the unveiling of this desire does not take place in the vastness of a grove or wood, but in the intimate secrecy of a "nook" (1. 7) where the flagrant nature of Sappho's ardour comes to make "Aphrodite pale" (1. 8). The Graeco-Roman goddess of beauty and love reinforces the symbolic analogies between the bee, Persephone, and the Sapphic lover. In some versions of her myth, Aphrodite destroys a king "who mated with her on a mountain top, as a queen-bee destroys the drone: by tearing out his sexual organs" (Pulham 2008, 58). Her power of castration, which originates in her own birth from Uranus's mutilated genitalia, also affects the priests who worship her as "a queen-bee" only after having performed acts of "ecstatic self-castration" (Pulham, 2008, 58). As a vicious lover, the goddess stings, wounds, emasculates, and even gives — symbolic or actual — death to her male followers.

Given her brutal and lethal ways of affection, Aphrodite does not confine her scope of influence to the sexual, nuptial, and romantic facets of love: she also embodies "the dark side of love, which is death" (Johnson, 1994, 80). In so doing, she inevitably intrudes into the Stygian territory of Persephone, queen of the netherworld. The reputed mythologist Karl Kéneyi writes:

In Greek southern Italy there are superb works of art that show how Persephone, the goddess of the underworld, can appear in the guise of Aphrodite, and how profound a religious experience underlay the Pythagorean doctrine that there were two Aphrodites, one of the heavens and one of the underworld. Aphrodite had her Persephone aspect (in Jaffé, 1999, 92).

In Michael Field's lyric III, Sappho wishes to emulate or even surpass the thanato-erotic paradigm of voracious desire instituted by Aphrodite. Although rejected by her beloved, Sappho is not a powerless victim of disdain. In her effort to transcend Aphrodite's lust, she articulates a sexual volition that presents her not only as an excessive lover, but even as a potential agent of death or castration. Sappho becomes a mad queen-bee, a nomadic Persephone and a dangerous Aphrodite intent upon draining her ferryman, consuming his scent and splendour, and subjecting him to a potential emasculation. Excessive and symbolically violent, Sappho's desire offsets her lamentable plight as a spurned lover by likening herself to a thirsty bee invested with the latent power to sting, possess and emasculate her drone. Viewed in this manner, Sappho embodies Hegel's notion of self-consciousness as a subjectivity that becomes too "certain of itself only by superseding the other" $(1979,109)$. In other words, Sappho's desire is asserted in such a way that it threatens to supersede and even throw her beloved into what Hegel metaphorises as "a life-and-death struggle" $(1979,114)$,

Mesopotamian goddess Ishtar; hence it became the plant of love [...] Aristophanes uses "myrtle" as a euphemism for the female genitalia [...] Myrtle is an evergreen and thus suggestive of life's power against death; in Drayton's words, "bay and myrtle, which is ever new, / In spight of winter flourishing and green" (Pastoral Eclogues 6). Perhaps for this reason it was frequently used in garlands and crowns at festivals and to deck tombs. Early Greek lyric poets spoke of twining roses with myrtle" $(2007,134)$. 
one in which Sappho can either rise as a fatal and radical lover or end up solipsistically condemned to a tragic end.

\section{A FIERY CORPORAL TRUTH AND A TRAGIC CIRCLE IN THE SECOND OCTAVE}

The second octave of poem III reverts exclamatorily to Sappho's complete lack of erotic bliss and calls into question the continuation of her anxious search: "Honey nor bee! the tingling quest / Must that too be denied?" (ll. 9-10). Deprived of the chance to be either a bee or honey for her beloved, the Sapphic voice is suspended in her erotic transit, living out an inordinate yet failed desire and fluctuating between her disinclination to renounce her quest and her deep self-awareness that she may never know the joy of embracing her beloved. Accordingly, the existence she must lead is nomadic, always incomplete, and at best animated by the imaginings of conjectural actions. Were her pursuit of love successful, she "would rest" (l. 11) in Phaon's bosom with her desire relying exclusively on the conditional tense to envisage its improbable fulfilment. Here the conditional mood serves a significant purpose: it enables Sappho to transcend her desolate facticity, prolong her romantic fantasies, and persevere in her quest. In this hypothetical sphere, Sappho gains access to a full garden of interjectional or ejaculatory pleasure: "O golden blossom wide! / O poppy-wreath, O violet-crown" (ll. 12-13). As a symbolically violent bee, Sappho transforms Phaon into a bower of open, receptive and colourful flowers symbolically associated with consolation, fertility, love and lust.

Sappho seems to be so self-absorbed in her conditional scenarios of erotic hope, that she comes to suddenly alter the grammatical tense of her conjectural actions by replacing the conditional form with a decisive verb in the present indicative: "I fling your fiery circlets down" (1. 14). In this manner, the fictitious act of union becomes not only less distant and more substantial, but also fierce and even fiery. Sappho comes close to what Catherine Maxwell $(2008,49)$ describes as the "fleshing-out of the imagination", which is a poetic and erotic process whereby the object of desire, although merely imagined, grows capable of firing and fuelling the desiring imagination in such a way that the poem acquires a deep degree of physical intimacy, thus narrowing the Cartesian gulf between mind and body. In other words, Sappho's erotic imagination becomes, as it were, a source of somatic feeling and fiery arousal as a result of a sudden process of temporal displacement. With the irrealis mood of conditionality giving way to the present indicative, Sappho's desire is endowed with a sense of reality whose truth-value resists the exclusive logic of empirical objectivity and incorporates the subjective categories of feeling as variants of truth.

The sense of truth that Sappho seemingly upholds is close to what Hegel $(1979,104)$ styles as "the truth of self-certainty". In her economy of desire, she appears to understand truth as self-assertion or appropriation in the sense that she confronts her beloved's objective absence by inventing his presence in conditional terms at first, then situating him in her immediate present, and thereby appropriating him into her subjective reality. Moreover, expressing herself in a realis mood marked by the present indicative, Sappho not only manages to actualise her desire within her own reality or made-up self-certainty, but she also charges it 
with corporeal energy. She penetrates her beloved's bosom, feels its fiery vitality-veracity, and defoliates it. In keeping with the apian tropes, she pollinates Phaon and strips him of his petals in a sexual assault that, despite its unilateral immanence, completes Sappho's desire into an intense experience wherein the imagination enables the body to feel the beloved's fire.

Nevertheless, the semicolon added in the sixth line of the second octave brings an end to the central part where the Sapphic voice has ideated a hypothetical yet self-certain wreathing or union with her beloved. Creating the effect of a circular composition, the second octave reverts to the initial question of the stanza and seems to provide an inauspicious answer at the end: if "the tingling quest" (1. 9) for love on which Sappho is embarked is "denied" (1. 10), then she will never discover "the joys o'er which bees murmur deep" (1.15). The resultant reality of erotic negation comprises the tragic possibility of the lover's absolute non-existence for the loved one. Bewailing her condition of being neither honey nor a bee, unable to sting love into the boatman she covets, the Sapphic lover contemplates the additional and terminal pain of having to relinquish her quest in the face of her beloved's contempt. The scenario she suggests here foreshadows the tacit presence of an inevitable death: standing no chance to assume the power of the Aphroditean queen-bee, with no flowers to drain, with no honey to be sampled, and with the likely end of her search, Sappho cannot help but contaminate her sense of love with the spectre of her own potential death. Divested of everything that can link her -if fictively - to her beloved, she drifts away from him, fails to win the Hegelian life-and-death struggle, and comes closer and closer to the Leucadian cliffs.

\section{FROM ASYNDETIC OTHERNESS TO TRAGIC RESOLUTION IN THE THIRD OCTAVE}

In the third and final octave of poem III, the symbolic violence of Sappho's desire adopts a new tropological representation - that of love as consumption or direct somatic incorporation: "Honey! clear, soothing, nectarous, sweet, / Oh which my heart would feed" (ll. 17-18). Sappho fashions a gastronomy of desire, and her imagined experience is sensorially intense. She perceives Phaon as a sensual type of honey that stimulates her sense of taste to an asyndetic extent: "clear, soothing, nectarous, sweet" (1. 17). However, this simple sequence of adjectives presents Sappho's erotic imagination not only as a bodily or sensorial space, but also as a limited one: the asyndeton suggests that Phaon transcends the Sapphic appropriation and assumes a sensuous transparency, gentleness, sweetness, and other qualities that remain unknown. In other words, the asyndeton exposes his "otherness as a pure being-for-self or as an absolute negation" (Hegel, 1979, 114). Phaon exists beyond the four adjectives Sappho attributes to him, although he paradoxically depends on them for his poetic existence. He exists within the Sapphic poem insofar as he instigates, maintains, and sweetens Sappho's desire, yet the open enumeration of his attributes endows him with a boundlessness of his own that eludes Sappho's erotic apprehension. In a way, Phaon proves to be ontologically dependent and independent at once in the sense that his identity is obliquely represented by the Sapphic voice, and yet this representation per se discloses its own limitations by 
acknowledging asyndetically that Phaon's honey may offer more than Sappho's senses can perceive. His status is thus both immanent and transcendent.

As an immanent presence in poem III, Phaon falls prey to a voracious rhyme between "feed" (1. 18) and "greed" (1. 19). He becomes a sensuous object of consumption for a transgressive Sapho whose sexual appetite is not merely a Hegelian exhibition of desire, but a moral perversity altogether. Archetypically, female hunger carries pejorative connotations of sin, shame and subversion, thus prescribing the dangerous binomial femininity-voracity as an expression of "unspeakable desires for sexuality and power" (Michie, 1987, 13). Accordingly, Sappho's appetite for Phaon does not respect "the notion that a true lady has to be petite and fragile in order to emphasize her angelic, bodiless and passionless nature" (Domínguez-Rué, 2010, 297). Instead, what the Sapphic lover feels is a hyperbolic physical greed that, by its own definition, exceeds the intensity of hunger, takes on a long magnitude, and thus reaches a voracity that is related to women's potential for sexual aggression. As a voracious bee, Sappho pictures her beloved again in an objectifying and possessive manner: Phaon is portrayed as a honeyed fruit, a succulent feast, and a piece of "golden meat" (1. 19). As discussed above, despite her disadvantaged position of disdained lover, Sappho does not succumb to defeatism, inaction, and infertile misery. Instead, she charges her frustrated sexual appetite with a greedy violence that makes her castrating behaviour manifest, so much so that it is inevitable to identify her with what Catherine Maxwell (2001, 7) terms the feminine sublime. Sappho, indeed, embodies "a penetrating and often aggressive energy which overwhelms or pierces a man's body and soul." Under the influence of this energy, imaginary though it is, Phaon undergoes "a passive feminisation" and bears the threat of castration (Maxwell, 2001, 7).

In her erotic gastronomy, Sappho entreats the personified deity of love to intervene in her favour and serve her with a feast made of her beloved: "Give me, O Love, the golden meat" (l. 19). This entreaty replaces the previous conditional mood with a couple of imperative verbs that frame an alternate form of intersubjectivity between Sappho and Phaon. Inside her own sphere of action, she avails herself of the resource of grammatical conditionality to appropriate or attract her remote object of desire: in spite of having no factual truth-value, the Sapphic act of conditional attraction ascribes some affective veracity or actuality to the beloved, making him more accessible and reachable in her desiring imagination. Outside her limited sphere of action, Sappho has to look for a divine alliance to intercede between her and Phaon. In her address to the god of love, she externalises her desire by means of directive illocutions that involve an intermediate agency whose superior power, she believes, may help her assuage or "stay" her "life's long greed" (1. 20). In both cases, the conditional mood and the divinity-oriented imperative open up two spaces, one internal and the other external, wherein the desirous subject attempts to reach out to her loved object regardless of how real or veracious the attempt is. Both modalities, the conditional and the imperative, operate as strategies or mechanisms that initiate and favour the erotic mediation Sappho needs to gain some sense of propinquity to Phaon.

In her metaphoric proximity to Phaon as an object of consumption, Sappho transforms him from an ontologically ambivalent type of honey into a semi-divine piece of "golden meat" 
(1. 19). He experiences a peculiar kind of apotheosis in personifying the ambrosia or nectar "in which the gods delight" (1. 21). His presence among the gods has a twofold effect: his ontological stature rises, yet so does his distance from Sappho. By comparing him to divine food, the Sapphic lover elevates his condition to the metaphysical pedestal of the immortals. The asyndetic boundlessness he appears to possess becomes more patent now: Phaon enters a supra-Sapphic space of transcendence, gaining the highest esteem or idolatry that a beloved can inspire and, paradoxically, making it all the more unlikely for the lover to reach him. In deifying Phaon as an ambrosial meal, Sappho inevitably widens the barrier between her mundane self and the divine object of her desire with the detrimental result that her greed loses almost all prospects of finding assuagement in view of the divine remoteness her beloved has assumed. This detriment, however, overturns itself and becomes a promise in an absolute sense, for it implies a paradoxical benefit in the sense that it guarantees the continuation of the erotic quest. M. C. Dillon explains this paradox in his prosopography of the romantic lover/beloved:

In deifying the beloved, the romantic lover at the same time places a barrier between himself and the object of his desire. He keeps his quest alive by strategies designed to preclude the contact with or carnal knowledge of his beloved [...] The beloved, for her part, is complicit in this prohibition and seeks always to remain aloof, elusive, unattainable, mysterious, in any case, unpossessed $(2001,58) .4$

The quest is not denied. The unreachability of the deified beloved, far from deterring Sappho, situates her in a state of ceaseless transit and ontological ambivalence: she is and is not with Phaon, possessing him imaginarily, resisting his disdainful absence, roving for his honey, and permanently advancing towards him. Sappho keeps her quest ongoing, finds her raison d'être in it, invents an affective —often violent - contiguity to her beloved, and exhibits a desire that can only grow asyndetically. Sappho can cling on to the possibility of a limitless quest. As Anne Carson $(1986,26)$ would put it, Sappho is forever in the reach: her sense of "love is characterised by longing, striving, and incompleteness", and these feelings leave her in suspension, in the process of reaching out, and constantly becoming in the Hegelian sense of the participle. ${ }^{5}$ Her being is thus a dynamic form of existence with a permanent telos or hope for erotic fulfilment.

4 It is worth noting that the pattern of romantic divinisation that Dillon discerns in his study of different cultural (specifically literary) traditions reflects a clear distribution of gender roles: it is the male lover that takes the active part and deifies the female beloved, who is elusive and ultimately inaccessible. Nevertheless, as argued earlier, Long Ago transgresses and queers such a pattern by presenting Sappho as a greedy romantic idolater and her beloved Phaon as a castrated unreachable deity.

5 Sappho may be understood as "the movement or transition" from being to nothingness and vice versa (Burbidge, 2008, 35): she neither seizes nor loses her beloved — she is and she is not at once with him. While looking or reaching out to him, she is (in) the Heracletean flux of being and not being - entombed in - him. 
If Sappho's sense of taste has thus far been stimulated by a nearly divine Phaon-as-nectar, the sixth line of the third octave shows him as a visual source of pleasure: "That glistens tempting in my sight!" (1. 22). Sappho's desire is now scopophilic inasmuch as it stems from an attractive beloved that captivates her attention. Under the Sapphic gaze, Phaon has his androgyny or effeminacy enhanced to such an extent that he seems to play the part reserved in Western cultural aesthetics for passive-viewed-objectified women, whose physical presence merely presents itself or displays itself to be looked at within a visual regime in which, as John Berger $(1972,47)$ famously states, "men act and women appear. Men look at women. Women watch themselves being looked at". In her erotic discourse, however, Sappho overthrows such a regime by reversing its traditional roles: she becomes the subject of the active gaze and pictures Phaon as the glistening object of her aroused sight.

Sappho's scopophilia is not completely self-certain or self-controlled, though. It is true that she acts, looks, and imposes her gaze, but in so doing she exposes herself to Phaon's autonomous presence. He does not fall passively under Sappho's visual control. Phaon seduces her: he "glistens tempting in my sight" (1. 22). He embodies the oxymoronic identity of the eroticising passive agent: although visually objectified, he does not lose the power to influence, allure and tempt his desiring gazer, who inevitably ends up relegated to the passive condition of the visible as a result of what Merleau-Ponty views as the crisscrossing or chiasmus "between the seer and the visible" (in Landes, 2013, 226). Sappho is the seer, the seen, and even the tempted. For his part, Phaon is not just a visual object and a tempter at once, but also an elusive, reticent, and ultimately unconquerable otherness that retreats from the Sapphic life-and-death struggle of desire and greed: "Phaon, thy lips withhold from me / The bliss of honey and of bee" (1l. 23-24).

The closing lines of lyric III (1l. 23-24) conceal two paradoxes and one resolution. The first paradox is the presence/absence of Sappho's beloved. Phaon is invoked in a direct apostrophe that serves the previous function of the conditional and the imperative in the sense that the beloved's absence becomes neutralised and the possibility of an illusively immediate dialogue arises with Sappho addressing Phaon as an accessible interlocutor. However, in their transparent meaning, the final lines shatter the apostrophic illusion of immediacy with the beloved: Phaon withholds from Sappho. His presence in her poetic imagination depends on fragile mechanisms of language that resist yet never abolish the crude reality of his absence. The second paradox affects Phaon's identity again. In the final lines, he becomes a mere synecdoche, a pair of lips and thus an objectified figure. Sappho reduces his otherness to a labial reference that presumably catches her entire erotic attention. Phaon only matters to Sappho in his condition of being a potential passive kisser. His passivity is made manifest by his withholding reaction. Sappho has the name of action, acts fully as an erotic agent and presumably approaches her beloved with a decisive kiss. Phaon retreats as a coy and elusive prey, and yet his withdrawal puts him in an ambiguous position of passivity and agency. In lyric III, he consistently comes across as an object, a reduced otherness and a potentially castrated drone at worst, but he seems to retain a significant degree of autonomy and power in his disdain towards Sappho. Formally, conditionally, imperatively or vocatively, Sappho 
projects a vital, belligerent and ravenous desire, but factually her ultimate position amounts to that of a rejected otherness. The resolution of lyric III is clear: Sappho is irrevocably losing the Hegelian struggle as an unrecognised lover. Her desire entails her self-destruction.

\section{CONCLUSION}

In this article, I have displaced the common critical narrative on Long Ago from its emphasis on queerness to the volume's intrinsic Hegelianism. As self-proclaimed advocates of Hegel's thought, the Fields seemed to deeply understand the workings of selfconsciousness, desire and otherness. Indeed, their Sapphic collection can be approached as a fruitful space laden with Hegelian tensions. In particular, lyric III amounts to a complex reflection on desire that lends itself to be read alongside the intriguing second chapter of Hegel's Phenomenology of Spirit. Undoubtedly, in light of the previous close reading, poem III is a tense, undetermined and ambiguous piece built upon a whole system of paradoxes. In the opening octave, the very structures of form and content come into conflict with the former creating an illusion of romantic union and the latter remarking Sappho's reality of lovelessness. In its formal anatomy, lyric III projects the culmination or gratification of Sappho's desire, but at the content level the factual imposes itself upon the ideal.

In the middle of the form-content agon, Sappho embodies an unstable subjectivity that wavers between imaginary satisfaction and factual despair, between vibrant nomadism and objective antagonism. However, Sappho deals with this existential indeterminacy with an acute sense of power and agency. Using a series of apian and mythic tropes, she constructs her own erotic identity on the grounds of a direct analogy with a frantic bee, a redefined active Persephone, and an all too dangerous Aphrodite. Sappho associates her extreme sense of desire with these figures in a - yet again - paradoxical idiom that conflates the delicacy of flowers and honey with an assertive romantic pragmatics of drainage, assault, flinging, penetration and ultimate consumption. The paradox of this idiom lies precisely in a wellwrought fusion of superficial connotations of vegetative grace and tenderness with implications of Hegelian belligerence and violence.

In addition to shaping a vegetative and mythic tropology of desire, Sappho transforms lyric III into a double text with an internal reality, as well as an external one. In the internal sphere of the poem, Sappho deploys the conditional and the present tenses to forge an illusion of propinquity and even bodily immediacy with her fiery beloved to the extent that she seems to shape her own notion of truth as subjective appropriation. In the external or referential sphere of the poem, Sappho uses two apostrophes that seem to make her object of desire more reachable and reducible. She turns to the deity of love to intervene between her and her beloved, seeing as her human power is directly met with failure. Towards the end of the lyric, she addresses her second apostrophe to Phaon himself in what appears to be an attempt to feel him as her immediate interlocutor. All in all, these internal or external strategies of desire offer a cogent portrayal of Sappho as a subversive and threatening erotic consciousness. 
However, in her struggle to conquer and drain Phaon, Sappho opens the way for a less strategic and more dangerous model of desire with its tacit direction towards the risk of symbolic or even factual death. With her insistence on Aphroditean excess, drainage and voracity, she suggests that her desire would reduce, annul or subject her beloved to a totalising regime of domination. Phaon would see his sense of freedom or individual self-certainty at risk of extinction. Nonetheless, there is a cruder presence of death looming over Sappho herself. Although she possesses a resolute sense of self-assertion and erotic power, she depends vitally on her desire for an unseizable, autonomous and asyndetic Phaon and this plight of existential dependence places her in a position of vulnerability that may all too readily lead her to a tragic denouement. As I have proven here, with only three octaves lyric III manages to dramatise this Hegelian evolution from desire and self-certainty to an extreme scenario of negated otherness or self-destroyed subjectivity.

\section{REFERENCES}

BERGER, J. 1972. Ways of Seeing. London: Penguin Books.

BERGK, T. 1882. Poetae Lyrici Graeci. Vol. 3. Leipzig: Teubner.

BlaIn, V. 1996. "Michael Field, the Two-Headed Nightingale': Lesbian Text as Palimpsest", Women's History Review, 5(2), pp. 239-257. https://doi.org/10.1080/09612029600200117.

Burbidge, J. W. 2008. The Historical Dictionary of Hegelian Philosophy. Ontario: The Scarecrow Press.

CANTILlO-LuCUARA, M. E. 2018a. "Michael Field's Sapphism: An Ontology of the Feminine in Long Ago (1889)”, Lectora. Revista de Dones i Textualitat, 24, pp. 205-222. https://doi.org/ 10.1344/Lectora2018.24.12.

CANTILlo-LuCuara, M. E. 2018b. "Michael Field's Long Ago (1889) as a Paradigm of Intertextual Theory: From Strangeness to Metaxology”, Cuadernos de Investigación Filológica, 44, pp. 185-210. https://doi.org/10.18172/cif.3442.

CANTILlo-Lucuara, M. E. 2018c. "Michael Field's Long Ago (1889): A Transcendental Mythopoesis of Desire and Death”, ES Review. Spanish Journal of English Studies, 39, pp. 69-96. https://doi.org/10.24197/ersjes.39.2018.69-96.

Dillon, M. C. 2001. Beyond Romance. New York: State University of New York Press.

DomínGUEZ-RUÉ, E. 2010. "Sins of the Flesh: Anorexia, Eroticism and the Female Vampire in Bram Stoker's Dracula”, Journal of Gender Studies, 19(2), pp. 297-308. https://doi.org/10.1080/09589236.2010.494346.

Dubois, P. 2015. Sappho. London and New York: I. B. Tauris.

EAgleton, T. 2007. How to Read a Poem. Oxford: Blackwell Publishing.

EHNEN, J. R. 2008. Women's Literary Collaboration, Queerness and Late-Victorian Culture. London: Routledge.

Evangelista, S. 2009. British Aestheticism and the Ancient Greece: Hellenism, Reception, Gods in Exile. Basingstoke: Palgrave Macmillan.

FERBER, M. 2007. A Dictionary of Literary Symbols. Cambridge: Cambridge University Press. FiELD, M. 1889. Long Ago. London: George Bell and Sons. 
FiELD, M. 1933. Works and Days: From the Journal of Michael Field. Ed. T. Sturge Moore. London: John Murray.

Foley, H. (ed.). 1999. The Homeric Hymn to Demeter: Translation, Commentary and Interpretive Essays. Princeton: Princeton University Press.

Hegel, G. W. F. 1979. Phenomenology of Spirit. Trans. A. V. Miller. Oxford: Oxford University Press.

JAFFÉ, A. 1999. Apparitions: An Archetypal Approach to Death Dreams and Ghosts. Einsiedeln: Daimon Verlag.

Johnson, B. 1994. Lady of the Beasts: The Goddess and Her Sacred Animals. Rochester: Inner Traditions International.

LANDES, D. A. 2013. The Merleau-Ponty Dictionary. Oxford: Bloomsbury.

Leighton, A. 1992. Victorian Women Poets: Writing Against the Heart. Oxford: Harvester Wheatsheaf.

MAdDEN, E. 2008. Tiresian Poetics: Modernism, Sexuality, Voice, 1888-2001. Madison: Fairleigh Dickinson University Press.

MaXwell, C. 2001. The Female Sublime from Milton to Swinburne: Bearing Blindness. Manchester and New York: Manchester University Press.

MAXWELL, C. 2008. Second Sight: The Visionary Imagination in Late Victorian Literature. Manchester and New York: Manchester University Press.

MichIE, H. 1987. The Flesh Made Word: Female Figures and Women's Bodies. New York: Oxford University Press.

Olverson, D. T. 2010. Women Writers and the Dark Side of Late-Victorian Hellenism. Basingstoke: Palgrave Macmillan.

Parker, S. and VAdillo, A. P. (eds.). 2019. Michael Field: Decadent Moderns. Ohio: Ohio University Press.

PRINS, Y. 1999. Victorian Sappho. Princeton: Princeton University Press.

Pulham, P. 2008. Art and the Transitional Object in Vernon Lee's 'Supernatural Tales'. Aldershot: Ashgate.

STERN, R. 2002. Routledge Philosophy Guidebook to Hegel and the 'Phenomenology of Spirit'. London: Routledge.

StetZ, M. D. and WiLson, C. A. (eds.). 2007. Michael Field and Their World. Birmingham: The Rivendale Press.

Thain, M. 2007. 'Michael Field' Poetry, Aestheticism, and the Fin de Siècle. Cambridge: Cambridge University Press.

Thain, M. and Vadillo, A. P. (eds.). 2009. Michael Field, The Poet. Published and Manuscript Materials. Peterborough/Buffalo: Broadview Editions.

ThomAs, K. 2019. "Vegetable Love: Michael Field's Queer Ecology”, in Parker, S. and Vadillo, A. P. (eds.), Michael Field: Decadent Moderns. Ohio: Ohio University Press, pp. 25-46.

VADILLO, A. P. 2014. "Walter Pater and Michael Field: The Correspondence, with Other Unpublished Manuscript Materials", The Pater Newsletter, 65, pp. 27-85

White, C. 1990. "Poets and Lovers Evermore': Interpreting Female Love in the Poetry and Journals of Michael Field", Textual Practice, 4(2), pp. 197-212. https://doi.org/10.1080/ 09502369008582086. 
White, C. 1996. "Flesh and Roses: Michael Field's Metaphors of Pleasure and Desire", Women's Writing, 3(1), pp. 47-62. https://doi.org/10.1080/0969908960030104.

\section{ABOUT THE AUTOR}

Mayron Estefan Cantillo-Lucuara holds a PhD in Languages, Literatures, Cultures and their Applications, and he works as an Assistant Lecturer in English Studies at the Universitat de València (Spain). His research focuses on nineteenth-century poetry with special emphasis on how it responds to new formalist approaches, how it converses with continental philosophy, and how it is received in other literary traditions. He has written extensively on Michael Field in peerreviewed journals such as Lectora: Revista de Dones $i$ Textualitat, Miscelánea: A Journal of Anglo-American Studies, Anuario de Estudios Filológicos, Cuadernos de Investigaciones Filológicas or ES Review, among others. ORCID: 0000-0002-1298-8496 